\title{
PENGELOLAAN KONFLIK SOSIAL KEAGAMAAN DI PULAU LOMBOK
}

\author{
Lutfatul Azizah \\ Universitas Islam Negeri Mataram \\ Email: lutfatulazizah@uinmataram.ac.id
}

\begin{abstract}
Religious conflict is a socio-religious dynamic that can strengthen the identity of a group or it can damage the religious social order of a community group. Conflict management determines how conflict becomes a procession of building a community or will damage the socio-religious order of a community. Conflict must be resolved, but what is far more important than conflict resolution is conflict management. Good conflict management is seen from community resilience to conflict. Lombok has a long history of socio-religious conflicts including a long history of the Ahmadiyah conflict and a long history of conflict with the largest religious organization on the island of Lombok. If we look at the two long conflicts that have occurred, the management of the conflict is quite interesting. Where one of them is an example of failure in conflict management and the other is an indicator of success in conflict management. Therefore, not only these 2 long conflicts but several conflicts also become a reference in this conflict management analysis.
\end{abstract}

Keywords: Socio-religious conflict in Lombok, managing conflict, socioreligious conflict.

\section{A. Pendahuluan}

Indonesia negeri yang kaya akan keberagaman agama, suku, bangsa, ras, bahasa dan budaya. Keberagaman menjadi potensi yang akan memicu munculnya konflik. Konflik adalah proses sosial masyarakat. Konflik memiliki nilai positif dan negatif ${ }^{37}$, konflik yang dikelola dengan baik akan menjadi konflik yang bernilai positif, sebaliknya konflik yang di kelola dengan tidak baik akan mengakibatkan lebih banyak kerusakan dan kerugian. Beberapa daerah di Indonesia banyak sekali yang rentan akan konflik, bukan karena faktor daerah panas atau tidak, atau daerah yang dekat laut atau daerah penghasil garam atau tidak. Mitos yang berkembang di masyarakat mengatakan, mereka yang konsumsi garam

37 Novri susan, Pengantar Sosiologi Konflik dan Isu-Isu Konflik Kontemporer (Jakarta: Kencana, 2009), h. 35. 
cukup tinggi maka masyarakat tersebut memiliki tempramental yang tinggi. Daerah-daerah tertentu juga dianggap sebagai wilayah dengan tempramental yang tinggi, namun pada dasarnya potensi konflik bagi semua komunitas masyrakat sama saja dimanapun berada. Secara garis besar, di daerah yang rentan terhadap konflik bukan karena keadaan geografis melainkan karena faktor latar belakang sosial, politik dan ekonomi. Tingkat pendidikan yang kurang, mengakibatkan masyarakat banyak yang tidak bisa mencerna informasi dan mudah terprovokasi. Kesejahteraan ekonomi yang jauh dari harapan menuntut masyarakat untuk bersaing dengan keras untuk bertahan hidup.

Diantara daerah yang rentan terhadap konflik yaitu pulau Lombok, NTB. Pulau Lombok merupakan salah satu dari kepulauan Provinsi Nusa Tenggara Barat. Penduduk Lombok berjumlah kurang lebih 3,2 juta orang. ${ }^{38}$ Jika Manado dikenal dengan sebutan kota "Seribu Gereja"39, maka sama halnya dengan Lombok lebih dikenal dengan sebutan pulau "Seribu Masjid". Mayoritas masyarakat Lombok memeluk agama Islam dengan presentase $86,7 \%$. Pulau Lombok adalah kepulauan dengan suku yang disebut suku "sasak" dan bahasa lokal yang digunakan disebut "bahasa sasak". Namun di Lombok tidak hanya terdapat suku sasak melainkan beberapa suku lain juga seperti, suku Bajo (Bima), Jawa, Cina, Arab. Lombok dikelilingi dengan bentangan laut yang sangat luas dan indah. ${ }^{40}$ Sedangkan komposisi penduduk di Indonesia berdasarkan pemeluk agama terdiri atas berbagai macam agama. Dalam data Kementerian Dalam Negeri tahun 2018, penduduk Indonesia berjumlah 266.534.836 jiwa dengan 86,7\% beragama Islam (Indonesia merupakan wilayah dengan penduduk muslim terbanyak di dunia), 7,6\% Kristen Protestan, 3,12\% Kristen Katolik, 1,74\% Hindu, 0,77\% Buddha, 0,03\% Konghucu, dan $0,04 \%$ agama lainnya.

Lombok merupakan pulau yang rentan terhadap potensi konflik. Konflik-konflik sosial keagamaan yang terjadi di wilayah Lombok dapat dibedakan dalam tiga kategori, yaitu; konflik antar kampung, konflik keagamaan, konflik agraria, konflik ekonomi politik. Konflik antar kampung yang terjadi antara lain; bentrok antar kampung seperti konflikkonflik yang beberapa waktu lalu pernah terjadi di Karang Genteng dan Patemon, konflik dalam bentuk bentrok antar Karang Genteng dan Pagutan Presak, Ketare dan Penujak, Ketare dan Batujai, Ketare dan Sengkol, Ketare dan Tenandon. Konflik keagamaan antara lain;

38 Jeremy Kingsley daam Kegalauan Identitas : Agama, Etnisitas dan Kewargaan pada Masa Pasca- Orde Baru oleh Martin Ramstedt dan Fadjar Ibnu Tufail (Jakarta: Grasindo, 2011), h. 97.

39 Ilham Daeng Mangkello, Kota Seribu Gereja: Dinamika Keagamaan dan Penggunaan Ruang di Kota Manado (Manado: Ombak, 2010), h. 32.

${ }^{40}$ John Ryan Bartholomew, Alif Lam Mim Kearaifan Masyarakat Sasak, terj. Imron Rasyidi, (Yogyakarta: Tiara Wacana, 2001), h. 86. 
Ahmadiyah vs warga masyarakat, Jemaat Salafiyah vs warga masyarakat, Tarekat Siratal Mustaqim vs warga Kelurahan Gerunung Praya, NW Pancor vs NW Anjani, perusakan gereja 17 januari 2000. Sedangkan konflik politik ekonomi diantaranya; konflik pembangunan Bandara Internasional Lombok (BIL), bentrokan antara PNS Lombok Timur dengan Pemda Lombok Timur. ${ }^{41}$ Terlepas dari potensi konflik komunal yang tinggi, konflik agama sangat cepat terjadi karena fanatik masyarakat terhadap agama dan golongan.

Dengan kelengkapan peta lokasi dan peta konflik seperti diatas maka konflik dapat dengan cermat dikelola secara tepat. Oleh karena itu, pengelolaan konflik (Conflict Management) yang erektif dan efisien dapat diterapkan sebaik mungkin. Akan tetapi, pada saat sekarang ini tidak banyak orang yang mengetahui secara pasti bagaimana dan seperti apa pengelolaan konflik yang efektif dan efisien. Secara sengaja atau tidak keberpihakan menjadi kendala utama dalam pengelolaan konflik. Untuk itu, pendidikan tentang pengelolaan konflik yang efektif dan efisien harus dapat diberikan kepada setiap masyarakat layaknya pendidikan dasar.

Penelitian ini menggunakan metode library research. Penelitian ini mengumpulkan informasi atau data-data yang dimuat dalam artikelartikel baik artikel jurnal maupun artikel koran terkait dengan konflik sosial keagamaan yang terjadi di Lombok. ${ }^{42}$ Adapun data-data yang digunakan adalah data-data kajian konflik sosial keagamaan yang telah diteliti oleh peneliti sebelumnya. Dalam penelitian ini, melihat penyelesaian konflik yang pernah dilakukan merupakan fokus penelitian. Pentingnya melihat penanganan konflik yang pernah dilakukan merupakan bahan analisis dalam penelitian ini. Disamping itu, penannganan konflik yang sudah pernah dilakukan merupakan proses yang dapat dipelajari supaya kedepannya belajar dari kekurangan atau mempertahankan metode yang efektif dan efisien.

\section{B. Pembahasan}

\section{Pengelolaan Konflik (Conflict Management)}

Pengelolaan konflik merupakan salah satu alternatif pendekatan terhadap konflik. Seperti yang dinyatakan oleh Simon Fisher bahwa pendekatan terhadap konflik ada 4 yaitu: Pencegahan konflik, bertujuan untuk mencegah timbulnya konflik yang keras. Penyelesaian konflik, bertujuan untuk mengakhiri prilaku kekerasan melalui suatu persetujuan perdamaian dan menangani sebab-sebab konflik dan berusaha membangun hubungan baru dan yang bisa tahan lama diantara

${ }^{41}$ Suprapto, "Revitalisasi Nilai-Nilai Kearifan Lokal Bagi Upaya Resolusi Konflik", Walisongo, IAIN Mataram, No. 1. Vol. 21, Mei 2013, h. 27-28.

${ }_{42}$ M. Kholis Amrullah and M. Irfan Islamy, Perencanaan Penelitian: Perjalanan Sistematis Penemuan Teori, ed. Ani Cahyadi (Malang: CV. Literasi Nusantara Abadi, 2020), h. 12. 
kelompok-kelompok yang bermusuhan. Pengelolaan konflik, bertujuan untuk membatasi dan menghindari kekerasan dengan mendorong perubahan perilaku yang positif bagi pihak-pihak yang terlibat Transformasi konflik, bertujuan mengatasi sumber-sumber konflik sosial dan politik yang lebih luas dan berusaha mengubah kekuatan negatif dari peperangan menjadi kekuatan sosial dan politik yang positif. ${ }^{43}$

Dalam kajian konflik dan perdamaian kontemporer conflict management bertujuan mencegah konflik yang menghasilkan bentukbentuk kekerasan, baik langsung maupun struktural. Terutama pada bentuk kekerasan langsung. Rubenstein menyatakan bahwa "conflict management bertujuan me-moderation atau memberadabkan efek-efek konflik dan sebab-sebabnya". Teori conflict management yaitu bukan bagaiamana konflik diselesaikan tapi bagaimana cara mengelola konflik yang dapat mengurangi eskalasi kekerasan. Tantangan pada manajemen konflik adalah bukan menghapus konflik melainkan mengatasi perbedaan seproduktif mungkin. Secara eksplisit bahwa istilah conflict management adalah upaya pencegah konflik dari kekerasan tanpa harus mencapai penyelesaian masalah seperti kesepakatan damai "hitam diatas putih" yang hanya terkadang sebagai formalitas saja.44

Pengelolaan konflik atau sering disebut juga dengan istilah manajement conflict, atau disebut juga regulasi konflik seringkali digunakan sebagai istilah generik untuk meliputi seluruh penanganan konflik secara positif. Perlu ada pembedaan antara pengelolaan konflik dan penyelesaian konflik. Penyelesaian konflik bermakna tercapainya kesepakatan antara pihak-pihak bertikai yang memungkinkan mereka untuk mengakhiri sebuah konflik bersenjata. Istilah penyelesaian konflik dapat mengakhiri kekerasan dan menunjukkan finalitas dalam prakteknya, akan tetapi kelemahannya adalah memungkinkan untuk kembali terjadinya konflik dikemudian hari.

Kesulitan tersebut tidak hanya dirasakan berdasarkan pengalaman Indonesia, namun juga dialami oleh sejumlah negara di berbagai belahan dunia. Oleh karena itu, kendatipun upaya ini tidak akan bisa membuahkan hasil dengan cepat dan memerlukan waktu lama, bahkan mungkin melampaui generasi ini, namun usaha ini mutlak diperlukan. 45 Pemerintah saat ini secara formal berperan dalam konflik akan tetapi mereka hanya sampai pada tahapan penyelesaian konflik belum sampai

43 Simon Fisher, Mengelola Konflik - Keterampilan dan Strategi Untuk Bertindak (Jakarta: The British Council, Indonesia, 2001), h. 18.

44 Novri susan, Pengantar Sosiologi Konflik dan Isu-Isu Konflik Kontemporer (Jakarta: Kencana, 2009), h. 136-137.

45 Jamuin Ma'arif, Manual Advokasi: Resolusi Konflik Antar-Etnik dan Agama, (Surakarta: CISCORE Indonesia, 2004), h. 207. 
pada damai berkesinambungan. "Damai berkesinambungan"46 merupakan cita-cita besar yang harus segera diwujudkan dalam setiap konflik yang terjadi.

\section{Tujuan Pengelolaan Konflik}

Konflik dapat terjadi disegala bidang kehidupan. Tujuan pengelolaan konflik dapat dilihat secara positif maupun negatif. Secara positif, tujuan pengelolaan konflik adalah untuk memanfaatkan konflik itu demi perbaikan orang-orang yang terlibat, hubungan antar mereka, kualitas maupun kuantitas damai diantara masyarakat. Secara negatif tujuan pengelolaan konflik adalah agar konflik yang terjadi tidak mengganggu orang-orang yang terlibat, merusak hubungan antarmereka. Tujuan pengelolaan konflik secara negatif merupakan tujuan maksimal. Tujuan minimal pengelolaan konflik adalah memutuskan konflik itu, kembalinya tenang hubungan mereka, memulihkan stabilitas sosial. Sedang tujuan maksimalnya adalah agar terwujudnya damai berkesinambungan. 47

Sumber daya manusia, sumber daya finansial, sumber daya teknologi serta local wisdom dapat dipergunakan sebagai instrumen untuk menyelesaikan konflik demi menciptakan perdamaian. Oleh karena itu, manajemen konflik harus dilakukan secara sistematis untuk mencapai perdamaian yang berkesinambungan. Berikut adalah tujuan-tujuan dari manajemen konflik diberbagai bidang: 1) Mencegah gangguan kepada anggota kelompok untuk memfokuskan diri pada visi, misi dan tujuannya, 2) Memahami orang lain dan menghormati keberagamaan, 3) Meningkatkan kreativitas, 4) Meningkatkan keputusan melalui pertimbangan berdasarkan pemikiran berbagai informasi dan sudut pandang, 5) Memfasilitasi pelaksanaan kegiatan melalui peran serta, pemahaman bersama, dan kerja sama, 6) Menciptakan prosedur dan mekanisme penyelesaian konflik yang efektif dan kreatif, 7) Mengurangi kemungkinan pada sabotase bagi pihak yang kalah dalam konflik.

\section{Faktor yang Mempengaruhi Pengelolaan Konflik}

Berbagai jenis konflik yang terjadi seperti konflik antar pemeluk satu agama, antar umat berbeda agama, konflik antar organisasi keagamaan, konflik separatis bahkan dalam ruang lingkup atau aspek kehidupan manusia juga terdapat berbagai jenis konflik yaitu konflik dengan diri sendiri, konflik dengan sesama, konflik yang terjadi di lingkungan masyarakat, konflik dalam dunia kerja dengan segala aspeknya, konflik antar kelompok, golongan, ataupun perkumpulan sosial lainnya, juga

46 Martino Sardi, Berjuang Mengelola Konflik Demi Resolusi Damai Yang Berkesinambungan, (Yogyakarta: Pusat Studi HAM dan Demokrasi Universitas Atma Jaya,2008), h. 4.

47 Agus M. Hardjana, Konflik Di Tempat Kerja, (Yogyakarta: Kanisius, 1994), h. 44 . 
konflik antar suku, bahkan konflik antar negara.48 Upaya nyata yang dapat dilakukan dengan mengelola konflik atau manajemen konflik agar tidak berubah bentuk menjadi tindak kekerasan yang merugikan atau menimbulkan dampak yang lebih besar. Upaya pencegahan yang efektif adalah melakukan berbagai cara, yakni advokasi atau gerakan yang bisa mereduksi potensi-potensi konflik dalam kehidupan masyarakat jika itu adalah konflik sosial. Caranya dengan mendampingi kelompok-kelompok atau kantong-kantong masyarakat yang rentan terhadap konflik. Gerakan itu harus dilakukan secara terus menerus. Fokusnya pada mereduksi persoalan dalam kehidupan manusia, misalnya ekonomi dan pendidikan. Selain itu, gerakan pemberdayaan terhadap kualitas pemahaman agama dan wawasan kebangsaan mutlak diperlukan.

Kusutnya aturan terkait dengan keberadaan kelompok etnik dan organisasi-organisasi sosial keagamaan, bercampurnya kepentingan ekonomi dan politik ke dalam wilayah ini, serta luka sejarah yang terlanjur mengkristal, juga perlu diselesaikan. Namun, beragam bentuk dan upaya penyelesaian itu tidak bisa dirasakan manfaatnya dengan cepat (instan), namun memerlukan waktu lama. Konflik yang terjadi dapat meningkat dan mendatangkan banyak kerugian tetapi dapat juga mereda dan membawa banyak manfaat bagi orang, dan juga bagi hubungan antar orang yang terlibat. Hal ini amat ditentukan oleh cara pengelolaan konflik tersebut. Sedangakan pengelolaan konflik terutama konflik sosial keagamaan sendiri dipengaruhi oleh berbagai faktor, antara lain: a) Hubungan antara orang-orang yang ada dalam konflik, sebelum konflik terjadi. Hubungan yang sebelumnya sudah buruk tentu saja membuat pengelolaan konflik menjadi lebih sulit daripada hubungan yang sebelumnya baik-baik saja. b) Watak orang yang terlibat, dan keseimbangan kekuasaan antar mereka. Jika orang-orang yang terlibat sama-sama keras kepala dan kekuasaan mereka seimbang, pengelolaan konflik mempunyai kemungkinan lebih tersendat-sendat daripada jika orang-orang yang terlibat seimbang mentalnya dan yang satu lebih berkuasa daripada yang lain. c) Risiko yang dihadapi oleh orang-orang yang terlibat bila bertemu untuk mengelola konflik yang mereka alami. Pengelolaan yang dilakukan dalam suasana aman apa pun akibatnya tidak amat berat; berbeda dengan pengelolaan dalam situasi terancam, akibatnya cukup berat bagi salah satu untuk kedua belah pihak yang terlibat. d) Hakikat konflik. Konflik yang relatif besar, berlangsung keras, bersifat menentukan, rumit, menyangkut banyak hal dan banyak pihak, tentu lebih berat pengelolaannya daripada konflik yang kecil, lunak, tidak menentukan, sederhana dan menyangkut hal atau pihak terbatas saja. e) Masalah yang menjadi inti konflik dan pemahaman bersama tentang isi dan pentingya masalah. Bila masalahnya tidak berat, menyangkut perkara kurang penting dan kedua pihak yang berkonflik sudah sepakat tentang

${ }^{48}$ Martino Sardi, Berjuang Mengelola Konflik Demi Resolusi..., h. 1. 
isi dan pentingnya masalah dalam konflik, pengelolaannya lebih ringan daripada bila berkonflik tentang masalah berat yang masih diperdebatkan isi dan pentingnya. f) Modus atau cara mengelola. Modus atau cara mengelola konflik juga sangat penting karena cara ini akan meredam konflik sementara. Konflik perlu diredam untuk sementara sebelum menemukan strategi yang tepat untuk mengelola konflik. g) Perkiraan berhasil-tidaknya pengelolaan konflik. Pengelolaan konflik yang diperkirakan oleh orang-orang yang terlibat lebih banyak berhasil, pengelolaannya akan berjalan lebih optimis dan bersemangat daripada pengelolaan konflik yang diperkirakan belum tentu berhasil, apalagi diperkirakan pasti gagal. ${ }^{49}$

\section{Penyelesaian Konflik di Lombok}

Penjelasan mengenai penyelesaian konflik di Lombok kita mulai dari sejarah panjang konflik Ahmadiyah dan konflik organisasi keagamaan Islam yang terbesar di Lombok yaitu NW dan NWDI (pasca penyelesaian konflik di kukuhkan menjadi dua organisasi yang berbeda). Konflik Ahmadiyah di Lombok yang sudah dimulai sejak 1983-2018 menyisakan konflik yang tidak berkesudahan. Bahkan korban konflik yang saat ini masih disebut sebagai pengungsi Ahmadiyah yang tinggal di Asrama Transito sudah sampai 15 tahun lamanya tinggal di pengungsian tersebut. Meskipun hak-hak kewarganegaraannya diberikan seperti halnya hak KTP, berpartisipasi pada event politik nasional namun status pengungsi mereka masih belum bisa dikatakan selesai. Upaya penyelesaian yang di lakukan selama ini tidaklah relevan dengan tuntutan konflik yang terjadi. Upaya penyelesaian konfliknya dapat dikatakan upaya yang gagal untuk menyelesaikan konflik tersebut. Dimana upaya penyelesaian konfliknya tidak tepat sasaran. Memaksakan konsep penyelesaian yang dibangun dan memaksakan kepada salah satu pihak dalam hal ini kelompok Ahmadiyah. Oleh karena, pemerintah sudah melabeli mereka sebagai kelompok yang sesat atau kelompok yang harus dikembalikan ke jalan yang dianggap "benar" oleh pemerintah, jadi penyelesaian satu-satunya adalah Ahmadiyah berpindah kejalur yang dianggap "benar" tersebut. Metode penyelesaian konflik ini bukannya menyelesaikan konflik namun mentransformasi konflik kearah negatif. Transformasi konflik bisa terjadi secara positif bisa terjadi secara negatif50. Transformasi konflik yang positif dapat mendorong konflik menuju kepada penyelesaian. Sedangkan transformasi konflik yang negatif merubah jenis konflik seperti halnya konflik Ahmadiyah ini dari konflik kekerasan/konflik terbuka antara Jemaat Ahmadiyah dengan Masyarakat Desa Gegerung berubah menjadi konflik laten antara pemerintah dengan Jemaat Ahamdiyah.

Maka dari itu penyelesaian konflik tidak serta merta dapat dilakukan

\footnotetext{
${ }^{49}$ Agus M. Hardjana, Konflik Di Tempat Kerja..., h. 45-46.

${ }^{50}$ Ibid., h. 55.
} 
begitu saja, namun pengelolaan konflik juga penting dilakukan. Pengelolaan yang dimaksudkan adalah pengelolaan yang berarah kepada penyelesaian konflik yang positif. Contoh penyelesaian konflik lain yaitu konflik organisasi keagamaan terbesar di Lombok yaitu NW dan NWDI. Konflik ini dimulai sejak tahun 1998 sampai benar-benari dianggap selesai pada tanggal 23 Maret 2021. Proses penyelesaian ini dipimpin oleh Dirjen Administrasi Hukum Kemenkumham RI Cahyo Rahardian Mushar dan didampingi oleh Brigjen TNI Ahmad Rizal Ramadhani dan Kapolda NTB Irjen Pol M. Iqbal. Penyelesaian ini berakhir dengan mengalahnya TGB. Dr. Zainul Majdi yang dengan besar hati mengembangkan organisasi atas nama NWDI (Nahdlatul Wathan Diniyah Islamiyah) dan memberikan KH. H. L. Gd. M. Zainuddin Atsani., Lc.,M.Pd.I dengan leluasa mengembangkan organisasi atas nama NW (Nahdlatul Wathan).51 Hingga sampai saat ini kedua organisasi ini kemudian sudah tidak saling mengganggu atau menggugat eksistensi masing-masing.

Melihat dari proses penyelesaian konflik ini mediasi panjang yang dilakukan sehingga sampai pada keputusan damai tersebut yaitu dengan metode pelibatan pejabat negara dalam hal ini Dirjen Administrasi Hukum Kemenkumham RI. Hal ini membuktikan bahwa penyelesaian konflik yang dilakukan yaitu dengan metode peace building. Penyelesaian konflik dengan peace building saat ini dilakukan dengan teknik yang baru yakni pelibatan aparat kepolisian tapi tidak pada tataran penghentian kekerasan dengan peace keeping. Aparat keamanan menurut Simon Fisher biasanya diturunkan pada tahapan peace keeping atau penghentian kekerasan dalam konflik. Meskipun metodenya dengan kekerasan pula, namun dalam pelibatan aparat keamanan pada proses peace building menjadikan proses penyelesaian konflik lebih akurat dan efisien.

Selain kedua sejarah konflik keagamaan yang panjang ini, beberapa contoh konflik keagamaan yang terjadi seperti konflik antara Hindu dan Muslim di wilayah Lombok Barat juga kerapkali terjadi. Dibawah ini data sejarah konflik Lombok yang terjadi dalam rentan waktu 33 tahun:

\begin{tabular}{|c|c|c|}
\hline o & Konflik Sosial Keagamaan & $\begin{array}{c}\text { Ta } \\
\text { hun } \\
\text { Konflik }\end{array}$ \\
\hline & $\begin{array}{c}\text { Konflik Warga Karang Taliwang dengan Sindu } \\
19 \\
\text { dan Tohpati }\end{array}$ & $\begin{array}{c}19-2000 \\
\text { Konflik Ahmadiyah Lombok }\end{array}$ \\
\hline & $\begin{array}{c}\text { Konflik Antar Warga Tohpati dan warga } \\
\text { sekitarnya }\end{array}$ & 00 \\
\hline
\end{tabular}

51 Koran Merah, RTGB dan TGB Teken Kesepakatan 'Damai' Ada Yang Pakai NW dan NWDI, Diakses pada 29 November 2021 jam 21.13 WITA. 


\begin{tabular}{|c|c|c|}
\hline & Kerusuhan 171 & 20 \\
\hline & Konflik Antar Warga Nyangget dengan Saksari & 20 \\
\hline & $\begin{array}{l}\text { Konflik Antar warga Karang Tapen dan Karang } \\
\text { Jasi Lelede }\end{array}$ & 20 \\
\hline & $\begin{array}{l}\text { Konflik Antar Warga masyarakat Petemon dan } \\
\text { Karang Genteng }\end{array}$ & $\begin{array}{r}20 \\
03-2005 \\
\end{array}$ \\
\hline & Konflik Antar Warga Lk. Sindu dan Lk. Nyaget & 20 \\
\hline & Perusakan dan Penolakan Pura & 20 \\
\hline 0 & Konflik Masjid Kembar Kediri & 20 \\
\hline 1 & $\begin{array}{l}\text { Konflik Antar Warga Karang Bagu dan Karang } \\
\text { Taliwang }\end{array}$ & 20 \\
\hline 2 & $\begin{array}{ll}\text { Konflik Antar Warga Tohpati dan Karang Mas- } \\
\text { Mas }\end{array}$ & $\begin{array}{r}20 \\
12-2013 \\
\end{array}$ \\
\hline 3 & Konflik Antar Warga Tohpati dan Pandan Salas & 20 \\
\hline 4 & $\begin{array}{l}\text { Konflik Antar Warga Pejarakan dan penganut } \\
\text { aliran Salafi/ Wahabi }\end{array}$ & 20 \\
\hline
\end{tabular}

Berbagai konflik yang terjadi ini sebagian besar di selesaikan dengan metode mediasi yang dipimpin oleh aparat kepolisian. Ada konflik yang proses mediasinya terlihat dipaksakan dan ada yang proses mediasinya berjalan baik sehingga benar-benar merupakan penyelesaian konflik. Proses mediasi yang dipaksakan dapat mengakibatkan kembalinya terjadi konflik. Proses mediasi ini termasuk dalam proses mediasi yang tidak sesuai dengan tahapan mediasi dan menyalahi tujuan pengelolaan konflik. Maka dari itu penting ada tawaran pengelolaan konflik yang efektif dan efisien menuju penyelesaian konflik dengan damai yang berkesinambungan.

\section{Building}

Tawaran Pengelolaan Konflik Sosial Keagamaan dengn Peace

Peace Building adalah strategi atau upaya yang mencoba mengembalikan keadaan destruktif akibat kekerasan yang terjadi dalam konflik dengan cara membangun jembatan komunikasi antara pihak yang terlibat konflik. Peace Building lebih menekankan pada kualitas interaksi daripada kuantitas. Oleh karena itu menurut Muksin Jamil, ada lima hal yang harus diperhatikan dalam tahapan ini : a) Interaksi yang terjadi harus antara pihak-pihak yang memiliki kesejajaran status, b) Adanya 
dukungan dari lingkungan sosial,c) Komunikasi terjadi secara intim (bukan kasual), d) Proses komunikasi harus menyenangkan kedua pihak, e) Ada tujuan yang hendak dicapai bersama.52

Pada tahun 1975 Johan Galtung menciptakan istilah dalam karya rintisannya "Tiga Pendekatan untuk Perdamaian: Peace keeping, peace making, dan Peace building". Peace building adalah upaya untuk melakukan pencegahan terhadap konflik (tindakan preventif), manajemen konflik dan stabilisasi pasca konflik.53 Peace building dapat dilakukan dimana saja dan tidak terbatas oleh ruang dan waktu tertentu. Peace building mempunyai beberapa dimensi seperti; budaya, politik, dan ekonomi. Bahkan menurut Handwarker, perdamaian dimulai dari dalam diri manusia yang mempunyai kebutuhan dasar dan tingkah laku yang memotivasi untuk mempertahankan diri serta yang berhubungan dengan pemenuhan. Berdasarkan hal itu, interpersonal peace building (membangun perdamaian antar manusia) yang dianalogikan seperti membangun kembali jembatan-jembatan atau membuat hubungan antara individu dengan individu atau sekelompok individu. Sangat kecil kemungkinan untuk membangun perdamaian pada konflik yang terjadi tanpa memasuki tingkat tertentu dari kesepahaman yang baik.54

Berbicara tentang Pencegahan konflik atau tindakan preventif tidak hanya didefinisikan sebagai " Kegiatan yang bertujuan untuk meredakan situasi saat akan meledaknya konflik (pencegahan konflik dalam arti sempit), tetapi juga untuk mencegah terjadinya situasi yang sama pasca terjadinya konflik (pencegahan konflik dalam arti yang lebih luas). Artinya tindakan preventif tidak hanya diawal atau sebagai pembekalan bagi masyarakat supaya tidak terjadi konflik kembali. Tindakan preventif juga dilakukan pasca-konflik supaya konflik tidak kembali terjadi. Peace building adalah tindakan yang diambil pasca konflik maka peace building harus mengandung sifat preventif. Tindakan preventif sebelum konflik dan pasca konflik memiliki prinsip yang berbeda. Preventif diawal sebelum terjadinya konflik adalah pemeliharaan masa-masa damai, sedangkan preventif pasca-konflik adalah konstruksi kembali perdamaian.

Jika situasinya masih rentan atau belum terkonsolidasinya situasi damai ini, maka sewaktu-waktu bisa menyebabkan terjadinya konflik kembali pada masyarakat. Oleh karena itu, selain memastikan agar peace building berjalan efektif, upaya pencegahan konflik agar konflik kekerasan tidak kembali muncul menjadi agenda penting dalam masa pasca-konflik. Pencegahan konflik pada masa pasca-konflik, esensinya

52 Muksin Jamil, Mengelola Konflik-Membangun Damai (Semarang: Walisongo Mediation Center (WMC), 2007), h. 72.

53 Simon Duke dan Aurelie Courtier, "EU Peacebuilding: Concepts, Players And Instruments", dalam www.globalgovernancestudies.eu diakses pada tanggal 4 Mei 2015.

54 Simon Duke dan Aurelie Courtier, "EU Peacebuilding: Concepts, Players And Instruments", dalam www.globalgovernancestudies.eu diakses pada tanggal 4 Mei 2015. 
sama dengan memelihara perdamaian (peace keeping). Upaya ini sangat penting dilakukan di daerah-daerah pasca-konflik di Indonesia.

Menejemen konflik dilakukan untuk rekonstruksi dan rehabilitasi yang berarti pembentukan kembali segala aspek kehidupan yang diperlukan untuk memulihkan stabilitas sosial dan stabilitas politik di daerah yang pernah mengalami konflik. Peace building bisa dilakukan dengan membentuk penjaga perdamaian (sedapat mungkin menekankan kepemilikan lokal), perencanaan dan pelatihan operasi dukungan perdamaian, demobilisasi dan reintegrasi, reformasi pemerintahan (termasuk keadilan, organisasi sipil dan militer), hak manusia dan demokrasi, batas manajemen, polisi dan masalah lembaga pemasyarakatan, serta pengawasan. Menumbuhkan hubungan antara keselarasan keamanan dan pembangunan menuju perdamaian. Perdamaian dan keamanan sering dilihat sebagai dasar bagi kemajuan dan pembangunan yang berkelanjutan.

Menuju konsep perdamaian diperlukan identifikasi sebenarnya mengenai akar penyebab konflik hasil informasi dan analisis dari berbagai sumber sehingga menghasilkan perpaduan tentang peta konflik. Hal ini, pada gilirannya, akan menginformasikan mereka yang harus membuat perencanaan mengenai respon yang tepat untuk setiap situasi krisis yang akan terjadi. Pembangunan kebijakan dan program kerjasama menyediakan instrumen yang paling kuat bagi masyarakat untuk mengatasi akar penyebab konflik. Seperti yang diungkapkan Karl Raimund Popper: "Kita tidak menganggap diskusi sebagai kayu penghalang dijalan aksi, tapi sebagai langkah awal yang diperlukan untuk bertindak secara bijak". Ini bisa berlaku dalam konteks situasi krisis yang muncul untuk stabilisasi pasca-konflik. Sebagaimana ditunjukkan di atas, penekanan sekarang semakin pada stabilisasi pasca-konflik serta pencegahan konflik kembali. Kebutuhan informasi yang akurat dalam setiap kasus karena akan membantu untuk menentukan apa yang dibutuhkan di lapangan. Kebijakan dan instrumen perdamaian masyarakat tidak dapat dianggap eksklusif; sebaliknya, kebijakan bersifat lebih umum dan instrumen yang digunakan memiliki penerapan perdamaian yang lebih luas.

Konsep ini diambil dari konsep perdamaian Uni Eropa yang sedang dikembangkan. Tujuan utama dari Uni Eropa adalah untuk memastikan inklusifitas dari semua pihak untuk konflik yang lebih potensial, termasuk perwakilan dari masyarakat sipil. Inkulisifitas yang dimaksudkan adalah keikutsertaan berbagai pihak terkait untuk bersama-sama membina hubungan damai pasca konflik. Sifat normatif dari hubungan eksternal Uni Eropa yang paling mendasar yaitu hak dan kebutuhan orang, sama pentingnya dengan "keamanan negara". Oleh karena itu, Uni Eropa mendukung tata kelola yang baik dalam peace building serta dalam pelaksanaan strategi pembangunan perdamaian melalui penggunaan 
campuran instrumen yang tepat. Selain itu peletakan badan koordinasi lapangan juga tidak kalah pentingnya untuk tetap menjaga kesinambungan perdamaian.55

Menurut Johan Galtung, perdamaian adalah tidak adanya atau berkurangnya segala jenis kekerasan.56 Simon Fisher, mengartikan perdamaian sebagai suatu proses; suatu pertarungan multidimensional yang tidak pernah berakhir dalam usaha mengubah kekerasan. Perdamaian juga didefinisakan sebagai usaha menjalin hubungan antar individu, kelompok dan lembaga yang menghargai keberagaman nilai dan mendorong pengembangan potensi manusia secara utuh.57 Menciptakan perdamaian diperlukan pihak-pihak independen yang sanggup menjembatani kedua belah pihak yang bertikai. Perdamaian menjadi kajian spesifik yang mencoba menanggulangi permasalahan kekerasan. Kekerasan struktural mendapat respon dari konsep perdamaian positif sedangkan kekerasan langsung mendapatkan respon dari perdamaian negatif. Dua konsep perdamaian tersebut nantinya akan melahirkan apa yang dinamakan konsep perdamaian menyeluruh.

John Paul Lederach, sarjana lain dalam bidang studi perdamaian, menyerukan memperluas pemahaman kita tentang perdamaian. Peace building, menurut dia, "lebih dari rekonstruksi pasca-kesepakatan" dan "dipahami sebagai konsep yang komprehensif yang mencakup, menghasilkan, dan menopang penuh arah proses, pendekatan, dan tahapan yang diperlukan untuk mengubah konflik ke arah hubungan damai yang berkesinambungan. Istilah ini melibatkan berbagai kegiatan yang mendahului dan mengikuti perjanjian damai secara formal. Perubahan menuju perdamaian dipandang bukan hanya sebagai tahap dalam satu waktu atau suatu kondisi. Ini adalah konstruksi sosial yang dinamis. Lederach berbicara tentang transformasi konflik untuk mengelola kekerasan di semua tahapan-tahapannya. Istilah ini menandakan proses yang berkelanjutan yaitu perubahan dari negatif ke positif dari segala hubungan, perilaku, sikap dan struktur sosial. Pendekatan terpadu untuk pembangunan perdamaian harus memperhitungkan sifat kompleks dan multi-dimensi dari pengalaman manusia dan bergantung pada partisipasi sosial yang luas. "Pendekatan transformatif berkelanjutan menunjukkan bahwa kuncinya terletak pada hubungan para pihak yang terlibat, meliputi tingkat psikologis, spiritual, sosial, ekonomi, politik dan militer." Memupuk sebuah "infrastruktur untuk pembangunan perdamaian" berarti kita tidak hanya tertarik pada 'mengakhiri' sesuatu yang tidak diinginkan. Orientasi diletakkan pada

55 Simon Duke dan Aurelie Courtier, "EU Peacebuilding..., h. 20.

56 Johan Galtung, Studi Perdamaian dan Konflik, Pembangunan dan Peradaban (Surabaya: Pustaka Eureka, 2003), h. 21.

57 Simon Fisher, Mengelola konflik: keterampilan dan strategi untuk bertindak, terj. SN Karikasari, dkk (Jakarta: PT. Gramedia, 2001), h. 27. 
pembangunan hubungan dalam totalitas yang membentuk pola-pola, proses, dan struktur yang baru." 58

Lederach mendefinisikan penyelesaian konflik sebagai sebuah upaya untuk mengungkapkan landasan akar konflik yang bersifat struktural, relasional dan budaya: "saya menyarankan agar pembentukan perdamaian dipahami sebagai sebuah istilah komprehensif yang diperlukan untuk mentransformasikan konflik menuju kehubungan dan hasil yang berkelanjutan dan damai. ${ }^{59}$ Pembangunan perdamaian pascakonflik merupakan subjek khusus dan perlu mendapat perhatian yang khusus pula. Pembangunan perdamaian pasca-konflik menghadapi masalah dan tantangan perdamaian khusus berupa kerentanan perdamaian dan hambatan perdamaian yang dihadapi daerah pascakonflik. Selain membutuhkan pendekatan pencegahan konflik secara khusus, terutama untuk mencegah agar konflik tidak kembali terjadi (recurring conflict), juga diperlukan pendekatan penyelesaian dan transformasi konflik melalui pembangunan perdamaian. Pencegahan konflik dalam masa pasca-konflik memiliki arti khusus sama dengan pemeliharaan perdamaian sehingga kedua pendekatan ini, pencegahan konflik (conflict prevention) dan pemeliharaan perdamaian secara militer (peace keeping), harus dipadukan dan dijalankan secara continum dalam pembangunan perdamaian pasca-konflik.60

Sederhananya, tulisan ini ingin merekomendasikan teknik pengelolaan konflik dengan tindakan preventif dan metode peace building. Merujuk kepada tujuan dan faktor yang dapat mempengaruhi pengelolaan konflik yang dijelaskan sebelumnya maka metode pengelolaan konflik yang bisa dikatakan efektif dan efisien dalam artian atau indikator efektivitas dan efisiensi adalah pengelolaan konflik yang profesional. Jika kita belajar dari konflik-konflik yang terjadi di Lombok dan menelaah penyelesaian konfliknya maka cukup terlihat bahwa metode penyelesaian yang digunakan adalah tindakan taktis saja. Tindakan taktis yang dimaksudkan adalah hanya meredam konflik tanpa mencabut akar konfliknya. Sehingga tindakan preventif dan pembangunan damai pasca konflik merupakan metode yang cukup efektif dan efisien untuk pengelolaan konflik menuju penyelesaiannya.

Tawaran Pengelolaan Konflik Sosial Keagamaan dengan Damai

58 Simon Duke dan Aurelie Courtier, “EU Peacebuilding..., h. 4-5.

59 John Paul Lederach, Building Peace: Sustainable Reconciliation in Divided Societies (Washington, D.C.: U.S. Institute of Peace Press, 1997), 20. Dalam Conflict Prevention And Peace Building oleh Gabriella S. Buescher, h. 9-10.

60 Lambang Trijono, "Pembangunan Perdamaian Pasca-Konflik di Indonesia: Kaitan perdamaian, pembangunan dan demokrasi dalam pengembangan kelembagaan pasca-konflik", Jurnal Ilmu Sosial dan Ilmu Politik, Volume 13, Nomor 1, Juli 2009, h. 53. 


\section{berkesinambungan}

Pengelolaan konflik menurut Martino Sardi ${ }^{61}$ dibangun atas dasar penghargaan terhadap HAM. Ungkapan beliau menyerukan bahwa satu jiwa saja tidak mampu untuk diberikan nominal. Oleh karena itu konflik hendaknya mendapatkan perlakukan yang tepat demi mencapai kedamaian abadi untuk setiap orang. Damai atas konflik yang terjadi merupakan sebuah perjuangan yang seharusnya atas pihak yang berkonflik. Damai abadi atau damai yang berkesinambungan merupakan cita-cita ideal setiap orang dalam hidup sosialnya. Kita harus berjuang agar konflik itu memperoleh penyelesaian damai. Damai harus dipertahankan dan diperjuangkan secara terus-menerus tiada hentinya. Damai yang berkesinambungan adalah harga mati bagi bangunan prinsipprinsip relasi sosial masyarakat.

Dalam rangka menangani konflik yang besar, khususnya konflik antar kelompok, atau bahkan konflik antar negara, paling tidak haruslah ditempuh empat tahapan untuk sampai pada perdamaian yang berkesinambungan. Dalam konflik pada umumnya terdapat pelaku kekerasan dan korban, karena itu penanganan akan hal ini haruslah hatihati, berdasarkan fakta, kebenaran dan prinsip keadilan. Pihak-pihak yang berkonflik harus mampu untuk saling menerima prinsip itu. Adapun empat tahapan dalam rangka mengelola konflik meliputi:

Pertama, Intervensi penguasa yang berwewenang. Truth claim adalah akar konflik paling berbahaya dimanapun terjadinya konflik. Entah itu konflik kelompok etnik, agama, suku dan ras membutuhkan another between aktor konflik (pelaku konflik). Dalam sebuah negara demokratis pasti memiliki perangkat negara yang bertugas untuk menyelesaikan konflik, seperti di Indonesia. Organ pemerintah diharapkan tidak berpihak, tetapi menjadi organ yang terpercaya dan dipercayai oleh kedua belah pihak, sehingga pihak-pihak yang sedang terlihat dalam konflik tindak kekerasan itu mampu melihat suatu organ resmi yang diharapkan mampu untuk menjadi perantara penyelesaian konflik.

Intervensi pemerintah sebagai penguasa akan menunjukkan otoritasnya, yang memang mempunyai kewenangan untuk menciptakan ketenteraman dan damai kepada warganya. Kedua belah pihak atau lebih yang terlibat dalam konflik harus menyadari tanpa adanya intervensi ini, mereka tidak mampu untuk menyelesaikan konfliknya. Otoritas pemerintah ini, khususnya intervensi militer yang tidak memihak akan memudahkan kedua belah pihak meletakkan senjatanya, menghentikan perang atau tindak kekerasan dan mulai berunding.

Kedua, Intervensi pihak lain demi kemanusiaan. Dalam situasi

61 (Alm) Dosen Hukum dan HAM Universitas Muhammadiyah Yogyakarta pengampu matakuliah Manajemen Konflik dan Advokasi Sosial Pasca Sarjana UIN Sunan Kalijaga Yogyakarta Tahun 2013. 
konflik, intervensi kemanusiaan dinilai menjadi penting, karena disamping aksi kemanusiaan yang memang harus dilaksanakan, juga dapat ditempuh untuk mengadakan negosiasi dengan para elit yang terlibat dalam konflik, agar konflik dihentikan dan solusi damai dirintis. Ikut serta dalam intervensi kemanusiaan tidak mudah, kata tidak berpihak kepada siapapun, menguasai medan, menguasai tehnik intervensi kemanusiaan baik dalam hal merawat korban, memberikan makanan dan minuman serta diplomasi dan negosiasi untuk mencari berbagai kemungkinan duduk bersama, dialog, berunding dan menghentikan tindak kekerasan, sampai dengan damai. Intervensi kemanusiaan sebenarnya juga merupakan salah satu cara, agar negoisasi terhadap tindak kekerasan itu dihentikan. Bagaimana pun juga korban harus mendapatkan perawatan, diperhatikan dan dicukupi kebutuhan hidupnya. Intervensi kemanusiaan menjadi penting untuk menghantar ke arah negoisasi adanya suatu pertemuan, dialog dan kesepakatan pada pihak-pihak yang sedang terlibat. Dengan demikian jalan damai dapat dirintis.

Ketiga, Menciptakan dan membangun damai. Pembangunan itu menyangkut berbagai langkah yang harus ditempuh yakni masa transisi, rekonsiliasi, konsolidasi dan strategi masa depan demi perdamaian dan keadilan. Masa transisi dari situasi konflik ke masa damai, memerlukan suatu daya tahan tersendiri, kekuatan baru, pemikiran ke masa depan yang jelas dan menata hidup yang sejahtera. Masa transisi merupakan masa yang penuh pergolakan diri, dan dijamin dengan adanya penyelesaian masalah. Masa lalu yang jahat dilaluinya, masa penyelesaian masalah sebagai titik sejarah peristiwa penting, dan sampailah masa peralihan untuk mencapai damai.

Masa rekonsiliasi ditempuh dengan membuka jalan pengampunan, perdamaian, persahabatan dan sekaligus pengharapan akan jalan yang semakin jelas dari perdamaian itu, yakni suasana damai dan keadilan. Dalam masa konsilidasi, manusia akan dihadapkan dengan membangun diri yang kokoh kuat bersama dalam masyarakatnya. Seluruh daya, kekuatan, kemampuan, keahlian, keterampilan dan dirinya sendiri akan menjadi dasar membangun diri bersama kelompoknya dalam masyarakat yang tidak hanya memikirkan dirinya sendiri, tetapi juga kepentingan pihak lain. Konsilidasi menjadikan dirinya mampu untuk hidup dalam kebersamaan yang semakin berarti. Hal ini akan semakin kuat, bila didukung dengan penyusunan strategi yang kokoh kuat untuk masa depannya, bahwa dalam hidup ini damai sungguh-sungguh merupakan dasar untuk bersikap dan bertindak. 62

Terdengar sangat menjanjikan saat berbicara tentang "damai berkesinambungan", akan tetapi cita-cita inilah yang menjadi harapan setiap orang. Sepanjang kehidupan manusia tidak akan dapat dihindarkan

${ }^{62}$ Martino Sardi, “Berjuang Mengelola Konflik..., h. 4-7. 
dari konflik. Disinilah inti efektivitas dan efisiensi pengelolaan konflik yang menjadi dasar-dasar penyusunan strategi pengelolaan konflik. Niat baik dan ketulusan hati untuk mengelola konflik demi kemanusiaan adalah hasrat baik yang harus dimiliki untuk mewujudkan perdamaian.

Hal ini sejalan dengan salah satu contoh konflik yang telah disebutkan contohnya adalah konflik organisasi keagamaan terbesar di Lombok yaitu NW dan NWDI. Dengan metode yang sama seperti tawaran damai berkesinambungan diatas. Sebenarnya penyelesaian konflik dua kubu ini merupakan upaya untuk mewujudkan damai berkesinambungan tersebut. Berdasarkan tahapan-tahapan diatas pelibatan pihak yang berwewenang, pelibatan untuk kemanusiaan serta cita-cita damai bersama tersebut merupakan proses yang telah dilalui pada pengelolaan konflik organisasi keagamaan terbesar di Lombok tersebut. Sampai pada tahapan kesepakatan damai, meskipun pada dasarnya puncaknya bukanlah kesepakatan damai tersebut namun bagaimana kedua kubu tersebut mencabut akar perseteruannya masingmasing. Masing-masing pemimpin menginstruksikan kepada para simpatisannya untuk menghentikan pertikaian tersebut. Meskipun sebenarnya para simpatisannya merupakan hanya representasi dari konflik kedua pimpinan lembaga tersebut.

Namun berbeda dengan konflik Ahmadiyah yang terjadi di Lombok yang sampai saat ini masih belum mencapai tahapan penyelesaian. Hal ini disebabkan tidak ada satupun yang dapat memetakan konflik ini dengan pasti. Sebagian orang melihat peta aktor konflik ini antara masyarakat Desa Ketapang dan Jemaat Ahmadiyah Lombok. Namun sebenarnya konflik ini adalah diantara pemerintah dengan Jemaat Ahamdiyah Lombok yang dengan keras seolah-olah sudah sampai pada kesimpulan yang paten bahwa mereka (JAI) adalah kelompok agama Islam yang sesat sehingga jalan satu-satunya adalah Ahmadiyah harus kembali ke jalan yang dianggap "benar" oleh pemerintah. Pemerintah dalam hal ini yang seharusnya berperan sebagai mediator justru menjadi aktor dalam konflik. Sehingga sulit untuk dapat menemukan penyelesaian konflik yang efektif dan efisien. Namun jika berbicara pengelolaan konflik yang efektif dan efisien, tawaran pengelolaan konflik masih bisa dilakukan diantaranya dengan tindakan preventif membangun damai berkesinambungan. Peace building cukup efisien sebenarnya untuk dapat diberlakukan pada pengelolaan konflik kasus Ahmadiyah ini. Selain sejarah konflik yang panjang artinya waktu telah meredakan konflik, namun nasib korban konflik masih menjadi sumbu pendek yang sewaktu-waktu bisa saja meledak.

\section{Kesimpulan}

Berdasarkan jenis-jenis konflik, maka pengelolaan atau manajemen konflik juga bervariasi sesuai dengan kebutuhan situasi dan ciri dari 
masyarakat tersebut. Pengelolaan yang baik adalah menjadikan setiap pihak yang berkonflik sadar bahwa mereka membutuhkan perdamaian. Melalui kesadarannya itulah kemudian upaya-upaya penyelesaian konflik dapat direalisasi dengan baik. Mengelola konflik tidak mudah karena membutuhkan banyak energi dan sumberdaya yang perlu di maksimalkan dan di efektifkan. Konflik tidak selalu tentang gencatan senjata, karena konflik yang bersifat tidak terlihat justru lebih berbahaya. Pengelolaan konflik membutuhkan seorang mediator yang benar-benar menyadari akan kebutuhan solusi. Manajemen konflik adalah upaya untuk menekan konflik supaya tidak menjadi tindak kekerasan. Sebagaimana teori konflik bahwa konflik bisa bersifat positif dan bisa juga bersifat negatif, maka manajemen konflik bertugas untuk menuntun konflik menemukan nilai positifnya. Efektivitas dan efisiensi sangat dituntut dalam upaya manajemen konflik. Dengan prinsip-prinsip profesionalitas maka manajemen konflik dapat mencapai tujuan utamanya yaitu untuk mengantarkan konflik mencapai nilai positifnya. Pengelolaan konflik bertujuan untuk menemukan ideal resolution terhadap setiap konflik. Artinya resolusi terbaiklah yang dikembangkan oleh pengelolaan konflik. Peace building adalah salah satu instrumen pengelolaan konflik yang mengembangkan tindakan preventif sebagai tindakan yang lebih penting dari hanya menyelesaikan konflik. Peace building dengan cita-cita damai berkesinambungan dapat menjadi tindakan atau langkah yang memungkinkan untuk mencapai cita-cita perdamaian. Pengelolaan konflik melalui peace building dapat membantu transformasi konflik dari keadaan konflik menjadi situasi baru. Peace building bisa saja mengurangi ketegangan konflik, namun juga menjadi daya tahan atau protect masyarakat terhadap konflik kembali. Catatan penting untuk dikembangkannya peace building pasca konflik yaitu memperhatikan azaz-azaz tindakan preventif dan rasa kemanusiaan. Tindakan preventif dapat di lakukan dengan inklusifitas semua orang dalam upaya peace building. Inklusifitas ini nantinya yang akan membentuk daya tahan atau protect masyarakat terhadap terjadinya konflik kembali.

\section{Referensi}

Amrullah, M. Kholis, and M. Irfan Islamy. Perencanaan Penelitian:

Perjalanan Sistematis Penemuan Teori. Edited by Ani Cahyadi. Malang: CV. Literasi Nusantara Abadi, 2020.

Bartholomew, John Ryan, Alif Lam Mim Kearaifan Masyarakat Sasak, terj. Imron Rasyidi, (Yogyakarta: Tiara Wacana, 2001).

Fisher, Simon, Mengelola konflik: keterampilan dan strategi untuk bertindak, terj. SN Karikasari, dkk (Jakarta: PT. Gramedia, 2001).

Galtung, Johan, Studi Perdamaian dan Konflik, Pembangunan dan Peradaban 
(Surabaya: Pustaka Eureka, 2003).

Hardjana, Agus M, Konflik Di Tempat Kerja, (Yogyakarta: Kanisius, 1994).

Ilham Daeng Mangkello, Kota Seribu Gereja: Dinamika Keagamaan dan

Penggunaan Ruang di Kota Manado (Manado: Ombak, 2010)

Ismail, Nawari, Konflik Umat Beragama dan Budaya Lokal, (Bandung: Lubuk Agung, 2011).

Jamil, Muksin, Mengelola Konflik-Membangun Damai (Semarang: Walisongo Mediation Center (WMC), 2007).

Kingsley, Jeremy, dalam Kegalauan Identitas: Agama, Etnisitas dan

Kewargaan pada Masa Pasca- Orde Baru oleh Martin Ramstedt dan

Fadjar Ibnu Tufail (Jakarta: Grasindo, 2011).

Lederach, John Paul, Building Peace: Sustainable Reconciliation in Divided

Societies (Washington, D.C.: U.S. Institute of Peace Press, 1997), 20.

Dalam Conflict Prevention and Peace Building oleh Gabriella S.

Buescher.

Ma'arif, Jamuin, Manual Advokasi: Resolusi Konflik Antar-Etnik dan Agama,

(Surakarta: CISCORE Indonesia, 2004).

Susan, Novri, Pengantar Sosiologi Konflik dan Isu-Isu Konflik Kontemporer

(Jakarta: Kencana, 2009).

Lambang Trijono, "Pembangunan Perdamaian Pasca-Konflik di

Indonesia: Kaitan perdamaian, pembangunan dan demokrasi dalam pengembangan kelembagaan pasca-konflik", Jurnal Ilmu Sosial dan

Ilmu Politik, Volume 13, Nomor 1, Juli 2009.

Suprapto, "Revitalisasi Nilai-Nilai Kearifan Lokal Bagi Upaya Resolusi Konflik", Walisongo, IAIN Mataram, No. 1. Vol. 21, Mei 2013.

Martino Sardi, 2008, Berjuang Mengelola Konflik Demi Resolusi Damai Yang Berkesinambungan, Yogyakarta: Pusat Studi HAM dan Demokrasi Universitas Atma Jaya

Nurjannah, "Teori Konflik dan Penanganannya (Kajian Psikologi Sosial)”. Handout mata kuliah Psikologi Agama dan Resolusi Konflik Pascasarjana UIN Sunan Kalijaga Yogyakarta.

Kurnia, Ahmad, Manajemen konflik : Definisi, Ciri, Sumber, Dampak Dan Strategi Mengatasi Konflik dalam

http:/ / manajemenkomunikasi.blogspot.com diakses pada 07 Januari 2015.

Simon Duke dan Aurelie Courtier, "EU Peacebuilding: Concepts, Players

And Instruments", dalam www.globalgovernancestudies.eu diakses pada tanggal 4 Mei 2015.

Koran Merah, RTGB dan TGB Teken Kesepakatan 'Damai' Ada Yang Pakai NW dan NWDI, dalam

https://www.koranmerah.com/2021/03/23/rtgb-dan-tgb-tekenkesepakatan-damai-ada-yang-pakai-nw-dan-nwdi/ diakses pada 29 November 2021 jam 21.13 WITA. 